\title{
BEING THE CHANGE: SOCIAL JUSTICE IN EXTERNSHIP PROGRAM EVALUATION
}

\section{Katie Spillane*}

Around the globe, clinical legal education [CLE] narratives resonate with a desire to promote social justice and the vindication of human rights. Yet scholarship exploring CLE's accomplishment of these aims is scant and generally focuses only on student outcomes. This literature appears to be based not on theory and results, but hope: the hope that changed students will change the world. To invest on hope alone is unwise, particularly when all stakeholders face financially precarious times. In this context, this article argues that the existing focus on student outcomes is disproportionate and unhelpful. The existing narrow focus on student outcomes marginalizes other stakeholders and creates significant blind spots in program evaluation. This article proposes a broader analysis that would ask what value systems and power distribution CLE programs themselves create or reinforce, focusing on both the immediate impact of $C L E$ programming and reinforcing the values human rights education seeks to inculcate by incorporating these into the structure of CLE programs themselves.

Aux quatre coins du monde, le discours sur l'enseignement juridique clinique est empreint d'une soif de promouvoir la justice sociale et de défendre les droits de la personne. Pourtant, les travaux des universitaires portant sur l'atteinte de ces objectifs sont rares et se concentrent généralement sur les résultats touchant les étudiants. Ces écrits semblent fondés non pas sur des théories et des résultats mais sur l'espoir: l'espoir que des étudiants transformés transformeront le monde. Miser sur l'espoir seul est une erreur, surtout quand tous les intervenants sont aux prises avec la précarité financière. Dans ce contexte, l'auteure de cet article soutient que les efforts actuels ciblés sur les résultats touchant les étudiants sont disproportionnés et inutiles. Ce ciblage étroit marginalise les autres intervenants et crée de gros angles morts dans l'évaluation des programmes. Dans son article, l'auteure propose une analyse élargie qui pose la question de savoir quels systèmes de valeurs et quelle répartition des pouvoirs les programmes d'enseignement juridique clinique créent ou renforcent, l'accent étant mis sur les répercussions immédiates de ces programmes et sur le renforcement des valeurs que l'éducation aux droits de la personne humaine semble inculquer par l'intégration de ces valeurs dans la structure même des programmes en question.

\section{INTRODUCTION}

"I can't keep my clinic open if you don't send more students."

$$
- \text { Danielle }^{1}
$$

Katie Spillane is a lawyer in Montreal. She extends her sincere thanks to the clinics, students and professors who both fostered and challenged the reflections in this article especially Andrea Corbin, Me Helena Lamed, Nandini Ramanujam, Arpee Santiago, and Amparita Sta. Maria. 
Danielle's words rang in my ears long after I hung up the phone. As coordinator of McGill University's Legal Clinic Course [LCC], this was the first time I realized fully the impact our program could have on host organizations. ${ }^{2}$ The following summer, my participation in McGill's International Human Rights Internship provided fodder for further reflection on the relationships between law schools, host organizations, and students. ${ }^{3}$ Through that program, I spent three months at the Ateneo Human Rights Center [AHRC] in Manila - a centre whose flagship program was offering human rights externships to Philippino students. ${ }^{4}$ Though brief, these experiences led me to contemplate how clinical legal education programs effect social change. ${ }^{5}$

Around the globe, clinical legal education narratives locate the movement's genesis in a desire to promote social justice and the vindication of human rights. ${ }^{6}$ And yet, while clinical scholars have generated abundant scholarship regarding law and social change, ${ }^{7}$ scholarship exploring whether clinical legal education initiatives achieve these aims is scant. ${ }^{8}$ Instead, the literature appears to be "based not so much on theory as on faith and hope" and holds that the exposure clinical education provides will influence the thinking of law students who, as social elites ${ }^{9}$ in their respective environments, will

1 I draw on personal experiences throughout this article. All names have been changed to protect individual privacy.

2 For more information regarding McGill's Legal Clinic Course (LCC), see <http://www.mcgill.ca/law-studies/undergradprograms/clinical-legal-education/legal-clinic-course>.

3 For more information regarding McGill's International Human Rights Internship (IHRI), see online: <http://www.mcgill.ca/humanrights/clinical/internships>.

4 For more information regarding the Ateneo Human Rights Center (AHRC), see Roger Burridge et al, eds, Effective Learning and Teaching in Law (London: Routledge, 2002), online: $<$ http://www.ateneo.edu/ateneo-human-rightscenter $>$. Additional information is available in an unpublished document titled "The Internship Program" [on file with the author].

5 See, e.g., Katie Spillane, "Interns on Internships: Mise en abyme in Manila” (July 2014), online: http://blogs.mcgill.ca/humanrightsinterns/2014/07/ [Spillane].

6 See, among others, Helena Alviar, "The Classroom and the Clinic: The Relationship between Clinical Legal Education, Economic Development and Social Transformation" (2008) 13 UCLA J Int'l L \& Foreign Aff 197 [Alviar]; Philip F Iya, "Fighting Africa's Poverty and Ignorance through Clinical Legal Education: Shared Experiences with New Initiatives for the 21st Century" (2000) 1 Int'1 J Clinical Legal Education 13 [Iya, "Fighting Africa's Poverty"]; Gary Bellow, "On Teaching the Teachers: Some Preliminary Reflections on Clinical Education as Methodology," CLEPR Conference Proceedings, Buck Hill Falls (1973); Frank S Bloch \& MRK Prasad, "Institutionalizing a Social Justice Mission for Clinical Legal Education: Cross-National Currents from India and the United States" (2006) 13 Clinical L Rev 165 [Bloch \& Prasad].

7 Perhaps most famously, Gerald P Lopez, Rebellious Lawyering: One Chicano's Vision of Progressive Law Practice (Boulder, CO: Westview Press, 1992). For a good overview, see also (1996) 31 Harvard Civil Rights-Civil Liberties Review 415, an issue dedicated to examining the relationship between the law and social change featuring work by and about clinicians.

8 Minna J Kotkin, “The Law School Clinic: A Training Ground for Public Interest Lawyers" in Jeremy Cooper \& Louise G Trubek, eds, Educating for Justice: Social Values and Legal Education (Dartmouth, UK: Ashgate, 1997) at 130; Roy Stuckey, "Can We Assess What We Purport to Teach in Clinical Law Courses?" (2006) 9 Int'l J Clinical Legal Education 9 at 9 [Stuckey, "Can We Assess"].

9 References to the elitist nature of legal education are long-standing. By way of illustration, see Jerome N Frank, "Why Not a Clinical Lawyer-School?" (1933) 81:8 U Pa L Rev 907 at 921; Consultative Group on Research and Education, Law and Learning (Ottawa: Social Sciences and Humanities Research Council of Canada, 1983) at 19 [Arthurs' Report]. For compelling arguments that lawyers and law students are not unique in this respect, see Orly Lobel, "The Paradox of Extralegal Activism: Critical Legal Consciousness and Transformative Politics" (2007) 120:4 Harv L Rev 937. 
influence those around them and, ultimately, their societies. ${ }^{10}$ To invest heavily on hope alone seems unwise. ${ }^{11}$ Indeed, with all stakeholders facing financially precarious times, ${ }^{12}$ the question cannot be whether we can find "something" valuable in externships, but rather whether and under what circumstances the outcomes justify the trade-offs made in hours and dollars spent. ${ }^{13}$

To date, evaluation of clinical legal education programs has focused on two elusive components: the quality of the student learning experience and the long-term impact of clinical experiences on student decision-making. ${ }^{14}$ Long-term educational outcomes are notoriously difficult to measure. ${ }^{15}$ Indeed, some have suggested that "it would be indulgent and grandiose, not to say demeaning and unrealistic," to attempt to measure the change in outlooks, futures, and passions that such programs seek to inspire. ${ }^{16}$ With these considerations in mind, I suggest that the existing focus on student outcomes is disproportionate and unhelpful. ${ }^{17}$ While clinicians and clinical scholars "lament the declining numbers of students who enter public interest practice and the political deactivation of our client base ... we see no programmatic causation in our own work." ${ }^{, 18}$ Indeed, I will argue that a narrow focus on student outcomes marginalizes other stakeholders and creates significant blindspots in program evaluation. Instead, we must broaden our analysis to ask what value systems and power distributions our programs create or reinforce. ${ }^{19}$ Broadening the analytical lens to include the experiences and outcomes of other

10 Jessica I Yeh, "Promoting Human Rights in China through Education: An Empirical Impact Evaluation of the Swedish Approach from a Student Perspective" (2008) 10 Asia-Pac L \& Pol'y J 114 at 121; Nancy Maurer \& Liz Ryan Cole, "Design, Teach \& Manage: Ensuring Educational Integrity in Field Placement Courses" (2012) 19 Clinical L Rev 115 at 188; Bellow, supra note 6 at 377.

11 In the 2013-2014 academic year, McGill students alone invested over 20,000 hours in externship work (based on program requirements and student reports). Flagship programs like the AHRC also serve as models for developing new programs domestically and abroad. See Bruce A Lasky \& MRK Prasad, "Clinical Legal Education in Southeast Asia and India: A Comparative Perspective and Lessons to Be Learned" in Frank S Bloch, ed, The Global Clinical Movement: Educating Lawyers for Social Justice (New York: Oxford University Press, 2011) 39.

12 Adrian Evans, "Global Agendas, Cultural Capital and Self-Assessment of Clinical Legal Education Programs" (2012) 38 Monash UL Rev 55 at 65; Mary Jane Mossman, "Why We Shouldn't End Community Legal Clinics in the GTA" (2 October 2014), online: $<$ http://itunes.apple.com/ca/app/the-huffington-post/id306621789?mt=8>; McGill University, "A New Challenge Ahead," online: <http://www.mcgill.ca/budgetcuts/new-challenge-ahead>.

13 Eric M Eisinger, "The Externship Class Requirement: An Idea Whose Time Has Passed" (2003) 10 Clinical L Rev 659 at 676 [Eisinger]. See also Stuckey, "Can We Assess," supra note 8 at 141.

14 For a recent Canadian example of such evaluations, see Adam Vasey, "Social Justice Externship Report" (2015), online: http://www.uwindsor.ca/law/sites/uwindsor.ca.law/files/cljf-sj-externships_final_report.pdf [Vasey]. See also Sally Maresh, "The Impact of Clinical Legal Education on the Decisions of Law Students to Practice Public Interest Law" in Jeremy Cooper \& Louise G Trubek, eds, Educating for Justice: Social Values and Legal Education (Dartmouth: Ashgate, 1997) p. 154; Yeh, supra note 10; Jeff Giddings, "Contemplating the Future of Clinical Legal Education" (2008) 17:1 Griffith LR 1 at 12.

15 See, e.g., Spillane, supra note 5; Stuckey, "Can We Assess," supra note 8.

16 Hugh Brayne \& Adrian Evans, "Quality-Lite for Clinics: Appropriate Accountability within 'Live-Client' Clinical Legal Education” (2004) 6 Int'l J Clinical Legal Education 149 at 153.

17 An understandable bias given the pedagogic rather than administrative focus of teachers, see Eisinger, supra note 13 at 674.

18 Sameer M Ashar, "Law Clinics and Collective Mobilization" (2008) 14 Clinical L Rev 355 at 382 [Ashar, "Law Clinics"].

19 Sameer M Ashar, "Book Review: The Global Clinical Movement" (2012) 62:1 J Legal Educ 193 at 199 [Ashar, "Book Review"]. 
stakeholders allows us to focus on outcomes over which programs have an immediate impact, while reinforcing the values human rights education seeks to inculcate through the structure of our programs. ${ }^{20}$

\section{A. The Human Rights Externship}

Political lawyering, or whatever we choose to call it, simply describes a medium through which some of us with law training chose to respond to the need for change in an unjust world ... [and embraces] a community of men and women who try to make things "better than they found them."21

- Gary Bellow

Clinical legal education embraces a broad range of pedagogies. The term has been applied to virtually any law-related activity students engage in beyond the classroom - from pro bono work to judicial clerkships - as well as to traditional law school activities like mooting, legal writing, and research. ${ }^{22}$ Whether we locate the genesis of clinical legal education in the apprenticeships that characterized early North American legal education or in the access to justice movement of the 1960s which "farmed-out" students to resource-strapped organizations, ${ }^{23}$ externships - programs through which law students may earn academic credit under the guidance of a supervisor in an institution outside of the law school - are at the root of clinical legal education. ${ }^{24}$

Since the 1980s, however, clinical legal education has progressively retreated from the field to the law faculty. This shift is a direct result of focusing on the student experience. ${ }^{25}$ In-house clinics, today's clinical "gold-standard," 26 are widely regarded as allowing for greater quality control with respect to case selection, supervision, and feedback. ${ }^{27}$ Externships, in contrast, have been progressively left behind. $^{28}$ There are good reasons to revisit this choice. First, in-house clinics, the most resource

20 Deena R Hurwitz, "Lawyering for Justice and the Inevitability of International Human Rights Clinics” (2003) 28 Yale J Int'1 L 505 at 522. It is precisely because human rights work is a "values-driven" field that our programs should reflect these values.

21 As cited in Supriya Routh, "Experiential Learning through Community Lawyering: A Proposal for Indian Legal Education” (2011) 24 University of the Pacific McGeorge Global Business \& Development Law Journal 115 at 119.

22 Bellow, supra note 6 at 375.

23 See section II below.

24 JP "Sandy" Ogilvy, "Guidelines with Commentary for the Evaluation of Legal Externship Programs" (2003) 38:1 Gonz L Rev 155 at 179. See also Maurer \& Cole, supra note 10 at 120; Kelly S Terry, "Externships: A Signature Pedagogy for the Apprenticeship of Professional Identity and Purpose" (2009) 59 Clinical Legal Educ 240 at 243.

25 See section II below.

26 Eisinger, supra note 13 at 663.

27 See, among others, Alexis Anderson, Arlene S Kanter \& Cindy Slane, "Ethics in Externships: Confidentiality, Conflicts, and Competence Issues in the Field and in the Classroom" (2004) 10:2 Clinical L Rev 473; Roy Stuckey et al, Best Practices for Legal Education (Columbia, SC: Clinical Legal Education Association, 2007) [Stuckey, Best Practices]; Maurer \& Cole, supra note 10, Margaret Martin Barry, Jon C Dubin \& Peter A Joy, "Clinical Education for This Millennium: The Third Wave" (2001) 7 Clinical L Rev 1 [Dubin \& Joy]; Peter Jaszi et al, "Experience as Text: The History of Pedagogy at the Washington College of Law, American University” (1998) 5 Clinical L Rev 403.

28 Givelber et al, supra note 15 at 5. 
intensive of clinical models, are simply not a viable option in many educational settings. ${ }^{29}$ The externship is also a particularly productive model for teaching human rights law. Broadly defined, a human rights externship is "one that can illustrate to law students that there are career opportunities in cause-based lawyering and in functions such as building capacity within a society to operate in a rightscompliant fashion, where legal skills may be particularly useful., ${ }^{30}$

Although clinics taking an explicit human rights focus are relatively new to the scene, ${ }^{31}$ clinical legal education as a broader movement has long focused on civil liberties and rights in domestic law that are fundamentally similar to human rights. ${ }^{32}$ Frequently approached through an interdisciplinary framework, human rights work is therefore particularly suited to the externship model, which explicitly welcomes the input of actors beyond the law faculty. ${ }^{33}$ Most importantly, however, externships should be revisited because they require the greatest integration between the law faculty and social organizations. As such, they are an ideal site for creating a more "dialogic and dialectic relationship between social movement actors and legal educators." ${ }^{34}$ Locating externships in the history of clinical legal education is one way to bring ourselves up to speed on the current conversation between stakeholders in clinical education.

\section{A BRIEF HISTORY OF CLINICAL LEGAL EDUCATION}

The most momentous change in professional training over the past century has been the movement of professional education into the academy. ... a shift away from apprenticeship, with its intimate pedagogy of modelling and coaching, toward reliance on the methods of academic instruction... 35

- William Sullivan

29 Although budget information is difficult to come by, we can compare 2014 tuition payments - as low as $\$ 4,124$ at McGill (<http://www.mcgill.ca/law-admissions/undergraduates/costs $>$ ) and as high as $\$ 54,850$ at

$(<$ http://www.law.harvard.edu/prospective/gradprogram/llm/financial-aid/>) and infer that McGill's Faculty of Law's reported \$8.6 million unrestricted operating budget (see McGill University Budget Book FY2015 (April 2014), online: $<$ http://www.mcgill.ca/provost/budget/mcgill-university-budget-book $>$ ) is significantly smaller than Harvard's.

30 Kris Gledhill, "Establishing an International Human Rights Clinic in the New Zealand Context" (2013) 19 Int'1 J Clinical Legal Education 295 at 305.

31 See section II below.

32 Hurwitz, supra note 20 at 511. See McGill Legal Clinic Course, online: $<$ http://www.mcgill.ca/law-studies/undergradprograms/clinical-legal-education/legal-clinic-course> for a listing of McGill's Legal Clinic Course offerings, many of which focus on areas traditionally associated with human rights including Indigenous rights, health rights, and women's rights.

33 Rita Maran, "Teaching Human Rights in the Universities: Paradoxes and Prospects" in George J Andreopoulos \& Richard Pierre Claude, eds, Human Rights Education for the Twenty-First Century (Philadelphia, PA: University of Pennsylvania Press, 1997) at 195; Howard R Berman, "Teaching Human Rights Law" (1985) 35 J Legal Educ 428 at 435.

34 Janet Mosher, "Legal Education: Nemesis or Ally of Social Movements?” (1997) 35:3 Osgoode Hall LJ 613 [Mosher, "Legal Education"].

35 William M Sullivan et al, eds, Educating Lawyers: Preparation for the Profession of Law (San Francisco: Jossey-Bass, 2007) at 25. 


\section{A. The Early Days: Legal Education Moves from the Law Office to the Law School}

In North America, ${ }^{36}$ the path of legal education has led from the law office to the law school. ${ }^{37}$ In the 19th Century, aspiring lawyers began their careers as clerks and apprentices, ${ }^{38}$ with legal education first appearing in American universities in the mid-1800s ${ }^{39}$ and in Canada 50 years later. ${ }^{40}$ The shift was not uncontested. American universities fought "a pitched battle with the practitioners for supremacy in legal education," 41 their primary weapons the casebook and Socratic methods ${ }^{42}$ introduced by Harvard and Columbia deans Christopher Langdell and Theodore Dwight. ${ }^{43}$ As early as the $1930 \mathrm{~s}$, critics railed against the academic study of law, arguing that clinical experience was essential to exposing students to the realities of practice and the "human side of the administration of justice." 44 For their part, Canadian schools retained a practice-oriented approach well into the mid-20th Century, ${ }^{45}$ with some schools explicitly rejecting the casebook method. ${ }^{46}$

\section{B. Post-War Reconstruction: Refashioning Externships as a Social Justice Tool}

The end of the world wars brought many paradigm shifts, including shifts in legal education. The Universal Declaration of Human Rights, drafted by Canadian John Peters Humphrey in 1946, codified a set of values that many hoped would guide reconstruction and development worldwide. ${ }^{47}$ Activist lawyers like American Arthur Kinoy advocated for clinical legal education as a means of integrating human rights in legal education ${ }^{48}$ and urged legal educators to take on contemporary social justice cases. $^{49}$ American and Canadian students, unsatisfied with the constrained view from the ivory tower,

36 Clinical legal education is "not yet produced dialogically through the joint and equal contributions of clinicians within and outside the United States". Ashar, "Book Review," supra note 19 at 196. The history of clinical legal education has been written largely by and from the perspective of American scholars. Scholarship in the field is heavily coloured by the particularities of the American system. At the most basic level, many authors question whether the professionalization aims of clinical legal education are valid in countries outside of the United States, where legal education is not always approached a priori as professional education. Although limited by the existing literature, this brief history attempts to draw on other perspectives in the hopes of inviting a broader conversation.

37 Arthurs' Report, supra note 9 at 12.

38 Ibid at 13; Dominick R Vetri, "Educating the Lawyer: Clinical Experience as an Integral Part of Legal Education" (1970) 50 Or L Rev 57 at 57.

39 LCDR Byard Q Clemmons, "Updating Legal Education: A Proposed Curriculum Emphasizing Clinical Education" (1989) 12 Geo Mason U L Rev 57 at 59.

40 Arthurs' Report, supra note 9 at 13.

$41 \quad$ Vetri, supra note 38 at 58.

42 For an interesting discussion of whether the "Socratic" method is truly Socratic, see Thomas C Brickhouse \& Nicholas D Smith, "Socratic Teaching and Socratic Method" in Harvey Siegel, ed, The Oxford Companion of Philosophy of

Education (Oxford: Oxford University Press, 2009), p. 177.

43 Clemmons, supra note 39 at 60.

44 Frank, supra note 9 at 918. See also Roscoe Pound, "Law and Social Work" (1927-1928) 3 Ind LJ at 193.

45 Arthurs' Report, supra note 9 at 15.

46 Ibid at 17.

47 For a brief historical overview of human rights, see Kenneth Cmiel, "The Recent History of Human Rights" (2004) 109:1 American Historical Review 117. Universal Declaration of Human Rights, UN Doc A/810 (1948).

48 Hurwitz, supra note 20 at 523.

49 See, e.g., Robert S Pasley, "The Moral Basis of Legal Education as It Relates to Human Rights" (1968) 44 Notre Dame L Rev 1053 especially at $1063 \& \mathrm{ff}$. 
demanded more practical approaches to legal education. ${ }^{50}$ Both American and Canadian law schools responded to these calls primarily by creating externships, "farming out" students to public defenders and community legal aid offices. ${ }^{51}$

Reconstruction and decolonization also occasioned new law and development paradigms ${ }^{52}$ including the export of American models of legal education to Africa, ${ }^{53}$ South America, ${ }^{54}$ and the Philippines. ${ }^{55}$ In the 1970s, the Ford Foundation ${ }^{56}$ began doling out the funding grants which would secure the financial footing of clinical legal education in the United States, ${ }^{57}$ and disseminated American-style clinical legal education to countries like India, ${ }^{58}$ Colombia ${ }^{59}$ the Czech Republic,${ }^{60}$ and China ${ }^{61}$ Many of these "exported" programs met with limited success, ${ }^{62}$ perhaps because of the ill-fit of American educational culture, ${ }^{63}$ perhaps because of the simplistic assumptions regarding causality and the process of change ${ }^{64}$ Ford Foundation funding also facilitated a shift from viewing clinical programs as cooperative community efforts between law schools and legal aid offices to viewing clinical programs as pedagogical tools. ${ }^{65}$ Scholarship was seen as a means of legitimating clinical education within academe, and funding allowed scholars like Gary Bellow and Lucie White to invest considerable efforts in this

50 Kotkin, supra note 8 at 136; Arthurs' Report, supra note 9 at 16; Frank S Bloch \& Mary Anne Noone, "Legal Aid Origins of Clinical Legal Education" in Bloch, supra note 11, p. 153 at 156.

51 Suzanne Valdez Carey, "An Essay on the Evolution of Clinical Legal Education and Its Impact on Student Trial Practice” (2002) 51 U Kan L Rev 509; Bloch \& Noone, supra note 50 at 156.

52 The legacy of these paradigms lives on. See Yeh, supra note 10 at 125; Alviar, supra note 6 at 212.

53 Thomas F Geraghty \& Emmanuel K Quansah, "African Legal Education: A Missed Opportunity and Suggestions for Change: A Call for Renewed Attention to a Neglected Means of Securing Human Rights and Legal Predictability" (2007) 5 Loyola U Chic Int'1 LJ 87.

54 Erika Castro-Buitrago et al, "Clinical Legal Education in Latin America: Toward Public Interest" in Bloch, supra note $11,69$.

55 Lasky \& Prasad, supra note 11 at 38.

56 Created by Edsel and Henry Ford, the foundation is an independent, non-profit, non-governmental organization that seeks to "strengthen democratic values, reduce poverty and injustice, promote international cooperation and advance human achievement." See Ford Foundation, online: <http://www.fordfoundation.org/about-us/mission>.

57 Jeff Giddings et al, "The First Wave of Modern Clinical Legal Education: The United States, Britain, Canada \& Australia" in Bloch, supra note 11, p. 3 at 5 [Giddings, "The First Wave"].

58 Bloch \& Prasad, supra note 6 at 169.

59 Alviar, supra note 6 at 202.

60 Dubravka Aksamovic \& Philip Genty, “An Examination of Challenges, Successes and Setbacks for Clinical Legal Education in Eastern Europe" (2014) 20 International Journal of Clinical Legal Education 427 at 432.

61 Pamela N Phan, "Clinical Legal Education in China: In Pursuit of a Culture of Law and a Mission of Social Justice" (2005) 8 Yale Human Rts \& Dev LJ 117 at 128.

62 Bloch \& Prasad, supra note 6 at 169; Aksamovic \& Genty, supra note 57 at 432; Phan, supra note 61 generally.

63 American cultural imperialism is thinly veiled in the literature. See, e.g., TM Cooley, "Globalizing Clinical Legal Education: Successful Under Developed Country Experiences" (2003) 6 Journal of Practical \& Clinical Law 129 at 134: "The really enticing issue here is actually much larger than simply globalizing American legal education or even our system of law - it deals with teaching (spreading) American values, culture, and even our societal approach to life."

64 Yeh, supra note 10 at 126-127.

65 Kotkin, supra note 8 at 136. 
task. Their work leveraged clinical experiences to theorize new forms of progressive lawyering ${ }^{66}$ and now forms the bedrock of the narrative that roots clinical legal education in social justice aims. ${ }^{67}$

It was in this context that Canada's early clinics cropped up in the 1970s as components of provincial legal aid schemes or at the initiative of community groups. ${ }^{68}$ They were not greeted with open arms. Key actors in legal education regarded such programs as "a competitor for the soul of legal education ... and a device for anchoring the law school more solidly within the legal profession." ${ }^{\circ 9}$ The private bars offered indifference or, in some cases, opposition. ${ }^{70}$ Thus, despite the success of select programs like Osgoode Hall's Parkdale Community Legal Services, ${ }^{71}$ there was "very little change in the clinical legal education landscape" from the 1980 s onward. $^{72}$

\section{The 1980s: Retreat from the Field to the Faculty}

The 1980s were a time of general criticism of traditional legal education. A partial response to this criticism was the increased use of clinical legal education as a pedagogical tool and a broadening of its use beyond social justice applications. ${ }^{73}$ This shift amplified a "perennial and often tedious debate" as to the relative merits of focusing on social justice or student skill development. ${ }^{74}$ The American Bar Association [ABA] weighed in on this debate with the release of its 1992 McCrate Report. Affirming

66 Rose Voyvodic, “Considerable Promise and Troublesome Aspects': Theory and Methodology of Clinical Legal Education" (2001) 20 Windsor YB Access Just 111 at 114; Caroline Bettinger-Lopez, "Redefining Human Rights Lawyering through the Lens of Critical Theory: Lessons for Pedagogy and Practice" (2011) 18:3 Geo J on Poverty L \& Pol'y 337.

67 Interestingly, the role of human rights was prominent neither in these narratives nor in American legal education until the early 2000s. See Berman, supra note 33 at 428. More research is needed on this topic. One explanation might be that the United States and Canada had not - and have not - signed many significant human rights instruments. But, as recently as 2013, countries like New Zealand, which has signed most of the treaties, had yet to develop vibrant human rights clinics. Gledhill, supra note 30 at 308. It could also be that the human rights community turned its attention elsewhere, although scholars have pointed to the significant attention given to the legal community at the 1988 United Nations international seminar on teaching human rights. Maran, supra note 33 at 206. Or it could be that scholars simply felt that the need for pedagogies specific to human rights was "overinflated." Bettinger-Lopez, supra note 66 at 394 . It was not until the early 2000s that human rights clinics became a presence in the United States. Hurwitz, supra note 20 at 527 . This was also when Montreal's first human rights clinic, the Clinique internationale de défense des droits humains de l'UQAM was founded.

68 Giddings, “The First Wave," supra note 57 at 8.

69 Ibid.

70 Ibid at 10. Even today, some community organizers characterize Quebec's laws against student practice as protectionist.

71 See, among others, Frederick H Zemans, "The Dream Is Still Alive: Twenty-five Years of Parkdale Community Legal Services and the Osgoode Hall Law School Intensive Program in Poverty Law” (1997) 25 Osgoode Hall LJ 499.

72 Voyvodic, supra note 66 at n 18, 116. More research on Canada's particular history is needed. With respect, Voyvodic's analysis is overly reliant on US narratives and may have overlooked important Canadian developments. McGill's IHRI program, for example, was founded in 1992. By the early 2000s, nearly all Canadian law schools offered some form of experiential programming, but only two - University of Calgary and University of Manitoba - required student enrolment. Voyvodic, supra note 66 at n 18.

73 Clemmons, supra note 39 at 62.

74 Evans, supra note 12 at 69. 
that student outcomes were "increasingly incompatible with the needs of the emerging corporate law firms," the report advocated for more practice-relevant legal education. ${ }^{75}$

Although the direct impact of the McCrate Report is contested, there is no doubt that it contributed to the retreat of clinical education from field externships to the university. ${ }^{76}$ Clinical programs "once perceived as a radically new teaching methodology that also infused ideological social goals into law schools ... began to serve very different ends: career development for students and efficiency for the private bar. ${ }^{77}$ In response to the McCrate Report's criticisms and new ABA standards, ${ }^{78}$ qualitycontrolled in-house clinics that could more easily target specific skills and experiences would become the "gold standard" for clinical quality. ${ }^{79}$ Although externships still dotted the clinical landscape, they would become "the orphan children" of the clinical movement. ${ }^{80}$

\section{The 2000s: Professionalization of CLE in the Global North}

The trend towards the professionalization of clinical education aims has continued into the 2000s. In the United States, and in much of Canada, rising tuition costs have created increased pressure for the production of "practice-ready" lawyers. ${ }^{81}$ This rationale has caught the attention of audiences worldwide, motivating law faculties in Korea, ${ }^{82} \mathrm{Japan}^{83}$ and the United Kingdom ${ }^{84}$ to consider clinical legal education more seriously. Perhaps as a result, service users have become "fungible," their experiences providing the text from which to teach skills; public service is often considered little more than a "by-product".

Perhaps for this reason, authors working outside the Global North criticize the emphasis on student experiences and outcomes as indulgent. ${ }^{86}$ Simply put, these authors argue that subordinating access and social justice objectives to individualized educational objectives is a luxury their countries cannot afford. ${ }^{87}$ Indeed, many countries have given their universities explicit mandates to include social justice

75 Task Force on Law Schools and the Profession, Legal Education and Professional Development: An Educational Continuum (Chicago: American Bar Association, 1992) at 4 [McCrate Report].

76 Margaret Barry, "Clinical Legal Education in the Law University: Goals and Challenges" (2007) 89 Int'1 J Legal Educ 27 at 40.

$77 \quad$ Kotkin, supra note 8 at 138.

78 Hurwitz, supra note 20 at 524.

79 Eisinger, supra note 13 at 663.

80 Givelber et al, supra note 15 at 5.

81 Janet Mosher, "Carnegie, Professionalism \& Apprenticeships for Justice" (Keynote address delivered at the Canadian Association of Law Teachers Annual Conference, June 2014) at 2 (unpublished) [Mosher, "Carnegie, Professionalism”].

82 Patricia Goedde, "Globalized Legal Education, Human Rights Lawyering, and Institutional Form: The Case of a Refugee Law Clinic in South Korea” (2013) 20 Clinical L Rev 355 at 356.

83 Peter A Joy et al, "Building Clinical Legal Education Programs in a Country without a Tradition of Graduate Professional Legal Education: Japan Educational Reform as a Case Study" (2006) 13 Clinical L Rev 417 at 418.

84 Lydia Bleasdale-Hill \& Paul Wragg, "Models of Clinic and Their Value to Students, Universities, and the Community in the Post-2012 Fees Era” (2013) 19 Int'1 J Clinical Legal Education 257.

85 Minna J Kotkin \& Dean Hill Rivkin, "Clinical Legal Education at a Generational Crossroads: Reflections from Two Boomers" (2010) 17 Clinical L Rev 197 at 202.

86 Phan, supra note 61 at 141.

87 David McQuoid-Mason, Ernest Ojukqu \& George Mukundi-Wachira, "Clinical Legal Education in Africa: Legal Education \& Community Service” in Bloch, supra note 11, p. 23; Barry, Dubin \& Joy, supra note 27 at 36 ; Bloch \& Prasad, supra note 6 at 172 . 
in their curricula and to mobilize students as a resource for improving access to justice - not later in their careers, but while they are still students. ${ }^{88}$ Resolving these two points of view is well beyond the scope of this article, but those who would advocate for externships as more than skill workshops will need better evaluative tools to justify the continued pursuit of social justice goals.

\section{EVALUATING EXTERNSHIPS}

\section{A. Approaches to Program Evaluation}

Not everything that counts can be counted, and not everything that can be counted counts. - sign hanging in Einstein's office at Princeton University

All learning programs can benefit from systemic evaluation, regardless of their normative aims. ${ }^{89}$ Evaluations need not be approached as scientific research - their purpose is to maximize the utility of effort expended by answering specific questions regarding program objectives and outcomes. ${ }^{90}$ Without such reflection, programs risk producing random and undesired outcomes. ${ }^{91}$ Existing externship evaluation methods are inadequate. Although American regulators have formulated extensive frameworks for interpreting clinical learning outcomes, these frameworks have been criticized for failing to capture the live-wire "frisson" of clinical legal education" and for creating reductionist "ticks" that encourage game playing among academics, hosts, and students alike. ${ }^{93}$ Most importantly, they address only two stakeholders in the clinical relationship: students and law faculties. Evaluations that include explicit social objectives have also been criticized as overambitious ${ }^{94}$ in assuming law or social movements can engender social change. ${ }^{95}$ Some programs have experienced pushback when opposing interests have felt social justice efforts have gone too far. ${ }^{96}$

88 See, e.g., Phan, supra note 61 at 135; Iya, "Fighting Africa's Poverty," supra note 6 at 15.

89 Ogilvy, supra note 24 at 176.

90 Equitas, "Evaluating Human Rights Training Activities: A Handbook for Human Rights Educators" (Montreal: United Nations Office of the High Commissioner for Human Rights, 2011) at 20.

91 See, among others, Evans, supra note 12 at 57; Maurer \& Cole, supra note 10 at 141; Frank, supra note 9 at 921.

92 Brayne \& Evans, supra note 16 at 156.

93 Ibid at 153; Eisinger, supra note 13 at 659. As coordinator of the LCC, it was my experience that students and supervisors reported to meet pro forma requirements, sometimes failing to report real issues (absent supervisors, lack of work, problems with incompetent students) for fear of failing (students) or being denied future students (hosts).

94 Berman, supra note 33 at 434.

95 See generally Lobel, supra note 9; Mosher, "Legal Education," supra note 34 at 616.

96 Lauren Carasik, "Justice in the Balance: An Evaluation of One Clinic's Ability to Harmonize Teaching Practical Skills, Ethics and Professionalism with a Social Justice Mission" (2006) 16 Southern California Review of Law \& Social Justice 23 at 35; Yeh, supra note 10 at 129 \& ff. When I suggested the AHRC become involved in "naming and shaming" a nearby land dispute, one of my supervisors declined - not for want of belief in the merits of that work but because of the potential for violence against clinic staff. In the Philippine context, being on "the wrong side" of an issue not infrequently results in forced disappearance or extrajudicial killings. During my time at the AHRC, a focal project was the Center's coordination of an American Bar Association-sponsored training for prosecutors of such retaliation cases. See ABA, "Current Rule of Law Programs in the Philippines: Seeking Justice for Victims of Extrajudicial Killings,” online: <http://www.americanbar.org/advocacy/rule_of_law/where_we_work/asia/philippines/programs.html\#extrajudicial_killings $>$. 
New frameworks are needed. But the call to improve evaluations is neither an effort to "develop a monolithic response nor does it suggest that improvement comes easily." ${ }^{.97}$ Each program has a unique matrix of objectives and limiting factors. The costs and benefits of program choices will thus look different and be evaluated differently by different people, ${ }^{98}$ and "[c]linical courses can take many forms and still accomplish important educational functions if they are thoughtfully designed." ${ }^{99}$ With this in mind, it is perhaps more useful to focus on distributional consequences across structures and stakeholders than on "costs and benefits" per se. ${ }^{100}$ Focusing on distributional consequences encourages stakeholders to think beyond zero-sum resource allocation and refocus on the nature and quality of the relationships a program creates. Participatory program evaluation that asks whether program structures reflect the movements' own theories regarding power differentials ${ }^{101}$ will better promote critical reflection and the pursuit of social justice outcomes. ${ }^{102}$

\section{B. The Signature Pedagogy Framework}

What would such an evaluation look like? The answer may come from a major player in classical legal education: the Carnegie Foundation for the Advancement of Teaching. This American policy and research centre has created a framework for exploring signature pedagogies in professional education. ${ }^{103}$ Signature pedagogies are "types of teaching that organize the fundamental ways in which future practitioners are educated for their new professions ... the forms of instruction that leap to mind" when we think of a particular form of professional education. ${ }^{104}$ Signature pedagogies are pervasive in their respective fields, implicitly defining what "counts" as knowledge for a corps of professionals and defining how that knowledge is analyzed and accepted - or discarded. ${ }^{105}$ In legal education, acknowledged signature pedagogies include the Socratic and casebook methods of classroom teaching. Whether externships are or should become a signature pedagogy in legal education is beyond the scope of this article. ${ }^{106}$ Regardless of how we answer that question, the Carnegie framework for understanding and exploring signature pedagogies is useful in creating an evaluative framework for externships. Signature pedagogies have been interpreted as having four structural dimensions:

(1) A surface structure, consisting of observable physical and behavioural landscape:

- where does activity take place?

- who undertakes each task?

- what methods do the different actors use?

97 Bettinger-Lopez, supra note 66 at 398.

98 David Kennedy, “The International Human Rights Movement: Part of the Problem?” (2002) 15 Harv Hum Rts J 105

[Kennedy, "International Human Rights Movement"].

99 Roy T Stuckey, "Ensuring Basic Quality in Clinical Courses" (2000) 1 Int'1 J Clinical Legal Education 47 at 48

[Stuckey, "Ensuring Basic Quality”].

100 Kennedy, "International Human Rights Movement," supra note 98 at 105.

101 Bettinger-Lopez, supra note 66 at 392.

102 Equitas, supra note 90 at 11.

103 For more information, see Carnegie Foundation, <http://www.carnegiefoundation.org/>.

104 Lee S Shulman, "Signature Pedagogies in the Professions" (2005) 134:3 Dædalus 52 at 52.

105 Ibid at 54; Terry, supra note 24 at 248.

106 See generally Terry, supra note 24. 
(2) A deep structure, composed of the underlying intentions, rationale, or theory that the behaviour models:

- what motivates the stakeholders to engage in the exchange?

- what is being taught?

- to what ends?

(3) A tacit structure, including the values that the behaviour implicitly models:

- where do we locate knowledge about law?

- what kind of work or knowledge is valued?

- who is powerful?

- who is protected?

(4) A shadow structure, made up of behaviours and pedagogies that are not, or are only weakly engaged:

- what elements of the educational enterprise are not present? ${ }^{107}$

Thus, the signature pedagogy framework includes, but is not limited to, student outcomes. Crucially, the framework also broadens the analytical lens and requires evaluating how program structures engage all stakeholders: students, law schools, hosts, and service users. Thus, the signature pedagogy framework can facilitate the evaluation of whether the social justice values clinic programs seek to teach are embodied in the programs themselves. In the following sections, I draw on my experiences with the Legal Clinic Course (LCC), the International Human Rights Internship [IHRI], and the Ateno Human Rights Center (AHRC) to flesh out one way this framework may be applied.

\section{Surface Structure: Physical and Behavioural Building Blocks}

The signature pedagogy approach begins by focusing on the nuts and bolts of externship programs asking who is involved, what do they do and where do they do it? This analysis will reflect the quantitative data that paint a picture of what externship programs look like.

\section{(a) Who}

The four principal stakeholders in human rights externships - law faculties, students, host environments, and service users - all play important roles. Law faculties coordinate externship programs for a variety of reasons. They recruit and screen students, facilitate communication between students and hosts, and monitor the student-host relationship. Host organizations and service users are phenomenally diverse, their collective presence resulting from a broad range of motivations. ${ }^{108}$ Host organizations may seek student volunteers to meet staffing needs. ${ }^{109}$ In other instances, hosts are solicited by law faculties

107 William M Sullivan et al, eds, Educating Lawyers: Preparation for the Profession of Law (San Francisco: Jossey-Bass, 2007) at 24; Shulman, supra note 104 at 54-55.

108 Mary Jo Eyster, "Designing and Teaching the Large Externship Clinic" (1998) 5 Clinical L Rev 347 at 365.

109 Indeed, my own LCC clinic placement occurred because one of our clinics was short on volunteers. Because we could not find a student to fill an awkwardly timed gap in coverage, as coordinator I filled a four-month, six-credit placement. 
seeking to round out program offerings. ${ }^{110}$ In many instances, student initiative brings a new host into the fold of a clinical program. ${ }^{111}$ Host organizations are usually expected to provide students with supervision and "working material," be it research questions, service users with discrete legal issues, or specific projects.

Not all students can or do participate in externship programs - most cohorts are self-selecting. ${ }^{112}$ Of the three programs considered here, McGill's LCC is perhaps the most open - entry requirements are low and final student selection is left to host organizations. ${ }^{113}$ In contrast, both the IHRI and the AHRC are competitive and selective. ${ }^{114}$ Both require student applicants to interview with the program coordinator who, considering student preferences, matches successful applicants with a host placement. $^{115}$

\section{(b) Where}

Externships, by definition, occur outside the four walls of the law faculty. However, the geographical, cultural, and conceptual distances between the externship and the law faculty vary.

McGill's LCC offers placements for one or two semesters in a variety of externships throughout Montreal. ${ }^{116}$ Most hosts operate out of brick and mortar offices where students are expected to meet service users and perform their work. ${ }^{117}$ These environments range from church basements to hospitals, from offices to day centres. Students may or may not have a designated space within the host environment. Although some organizations host more than one student, most students will work alone. Reflecting Montreal's bilingual character, students are generally expected to offer assistance in English and French.

The AHRC's placements are similar. Most students are hosted in various non-governmental organizations located in Manila. ${ }^{118}$ In its own offices, the Center also hosts interns from abroad ${ }^{119}$ and,

110 In 2014, the LCC responded to increased student demand for placements in mental health and Aboriginal contexts by initiating contact with the Douglas Mental Health University Institute and the Native Women's Shelter of Montreal.

111 The IHRI's placement with the First Nations Child and Family Caring Society of Canada began as a student-initiated "independent placement."

112 See Yeh, supra note 10 at 138. Not all students participate in clinics for altruistic reasons. In my experience, motivations range from pass-fail course options, to exposure to a specific area of law, to just needing something relevant to fill a curriculum vitae for the summer.

113 All students in their third or fourth year may participate if they meet a baseline grade point average requirement of 2.7. Even if strictly applied, this requirement would disqualify only $5 \%$ of the student population (based on published grade reports. See McGill University, online: <http://www.mcgill.ca/law-studies/policies/grades $>$ ) and, in practice, exceptions are generally granted upon request.

114 While both programs accept students having completed their first year of study, placement availability is more limited.

115 For more information, see IHRI selection process, <https://www.mcgill.ca/humanrights/clinical/internships $>$.

116 For a list of the current LCC internships, $<$ https://www.mcgill.ca/humanrights/clinical/internships $>$. Summer students are also permitted to seek placements outside of Montreal but must receive faculty approval.

117 In some instances, students may work remotely. In the 2013-2014 school year, three students contacted me with concerns about their working environment. Without a clinic office space, they had difficulty finding places to store files and make confidential phone calls. Our efforts to provide space for the students in our in-house clinic were unsuccessful, and their experience suffered because of this.

118 No complete list of organizations is available at this time. Although the AHRC once viewed its domestic programs as a training ground for international internships, the foreign placement of the program was later discontinued. See Internship Program, supra note 4. 
during its eight-week summer program, interns from other domestic universities. ${ }^{120}$ Some placements revolve entirely around office-based work, others require students to visit service users in communities and courtrooms beyond their host institutions. ${ }^{121}$ For many, this fieldwork entails communication through interpretation since service users do not all speak English or Tagalog.

McGill's IHRI sends its students furthest afield with placements in countries around the world. ${ }^{122}$ Students are exposed to a wide variety of locations and facilities - from Manhattan highrises to offices without electricity or running water. ${ }^{123}$ During their 12 -week internship, most students also live in a country new to them, with all the linguistic and cultural gaps this may entail.

\section{(c) What}

Once students arrive on site, a working relationship begins. For most students, the transition is significant: the familiar physical and social classroom environment is replaced with a new landscape. Learning to adjust to and navigate this new landscape is part of the internship process. ${ }^{124}$ The degree to which this transition is facilitated varies. Of the three programs, the AHRC provides the most extensive preparation, requiring students to attend four days of basic orientation, covering a range of topics from team building, to cultural sensitivity, to substantive law. ${ }^{125}$ Program alumni are extensively involved in planning, coordinating, and facilitating subsequent placements. The IHRI program provides some predeparture guidance through a travel logistics information session and an alumni networking event. There are no formal preparation requirements with respect to cultural awareness or substantive law. After sending students a handbook by email, the LCC traditionally begins the academic year with a lecture on poverty law. ${ }^{126}$ With respect to substantive requirements, only students having completed two years of the McGill program may participate in the LCC.

On location, hosts may or may not provide further student orientation. ${ }^{127}$ To my knowledge, none of these programs provide preparatory training for host supervisors, but all communicate with hosts through written documentation. ${ }^{128}$ Although each program requires its students to introduce themselves as students, service users are generally treated as program inputs rather than as program participants or potential teachers. The input for student work varies - most engage either in general research projects or direct user services. In many instances, students work side-by-side with other legal professionals, but it

\footnotetext{
119 In the three months I spent at the AHRC, the Center hosted interns from China, Vietnam, and the United States.

120 The intention of hosting such students from other domestic universities is that these "replicate" students will be inspired and empowered to found similar programs at their home universities.

121 Debriefing sessions, Ateneo University, May 2014.

122 For a current list of IHRI placements, see $<$ https://www.mcgill.ca/humanrights/clinical/internships $>$, noting that some students complete their fieldwork in Canada.

123 Debriefing sessions, McGill University, September 2014.

124 Phan, supra note 61 at 142.

125 See Internship Program, supra note 4 at 4.

126 For at least three years, this talk was given by Professor Alanna Klein, who teaches poverty law at McGill, and has featured the reading Lucie White, "Subordination, Rhetorical Survival Skills, and Sunday Shoes: Notes on the Hearing of Mrs. G" (1990) 38 Buff L Rev 1.

127 Some interns are thrown right into the mix, while others are required to undergo substantial site-specific training. For example, the Montreal clinic Project Genesis requires students to undergo 30 hours of initial training.

128 The LCC, for example, provides hosts with a four-page guide.
} 
is not uncommon for students to work with little supervision or as the "legal branch" of an interdisciplinary team. ${ }^{129}$

All three programs cap off the learning experience with reflective components. The LCC requires periodic qualitative and quantitative evaluations from students and hosts, including a two-to-four page final essay in which students are asked to reflect on their experiences. AHRC students spend the entire eighth week of their internship on reflection and synthesis, with two full days dedicated to formal group reflection. IHRI students are required to complete a three-credit follow-up course upon their return to Montreal, engaging in a variety of projects designed to stimulate collective reflection on the internship experience. $^{130}$

\section{Deep Structure: Underlying Intentions, Rationales, and Theory}

A law school curriculum is necessarily contingent on the purposes of education. The system of organizing the subject matter for valid education depends on the goals of that education. The concept of validity implies that the process is achieving the desired goal. ${ }^{131}$

- Byard Q. Clemmons

If the surface structure consists of the observable behaviours and concrete realities of human rights externships, the deep structure requires analyzing the theories that support a given program. Here, we ask what we seek to teach and why. It is perhaps this level of analysis that resonates most deeply with the existing literature regarding externship objectives.

\section{(a) Teaching: Skills or Social Justice?}

By and large, concerns regarding quality of supervision and learning experiences have moved clinical education back into the law faculties. Indeed, the literature makes amply clear that "without the infusion of significant resources focused on training, supervising and perhaps paying the field supervisors, harried lawyers using unpaid assistants could not be transformed into supervisors who resembled clinical teachers." 132 Ensuring hard skill acquisition in the externship environment is perceived by many as a "chimerical" pursuit. ${ }^{133}$

It is clear, however, from the structure of human rights externships that this cannot be the only goal. Indeed, scholars have argued that hard skill checklists like those offered by the McCrate Report are irrelevant to teaching values of social and economic justice. ${ }^{134}$ In contrast, "[a]n appropriately designed externship program could expose students to contradictions, pressures and frustrations of practice

129 Interestingly, in my experience concerns regarding supervision tend to relate more to student anxiety about exceeding the bounds of permissible student practice and rarely relate to protecting clients from poor information.

130 See Course Syllabus at $<$ https://www.mcgill.ca/humanrights/clinical/internships $>$.

131 Clemmons, supra note 39 at 62.

132 Jaszi, supra note 27 at 411.

133 Barbara A Blanco \& Sande L Buhai, "Externship Field Supervision: Effective Techniques for Training Supervisors and Students" (2004) 10 Clinical L Rev 901 at 901 [Blanco \& Buhai]. See also Graeme Coss, "Field Placement (Externship): A valuable Application of Clinical Education?” (1993) 4 Legal Educ Rev 29 at 44; McCrate Report, supra note 75 at 271.

134 Barry, supra note 76 at 40. 
without having to hold these experiences out as models of good practice." ${ }^{\prime 35}$ Many externship programs have thus flipped clinical learning on its head: field experience becomes the subject and not the site of learning. ${ }^{136}$ Thus, critical analysis of systems and forms of lawyering observed in the field - learning how to learn from practice rather than learning to practice - is the essential skill students gain from the human rights externship. ${ }^{137}$ The extensive time the IHRI and the AHRC programs invest in providing opportunities for students to reflect on their experiences clearly indicates their commitment to this form of reflection.

Of course, this is not to say students have not learned, or cannot not learn, from the externship experience itself, but rather that the experience is enriched by later classroom learning. ${ }^{138}$ In a reflective class, students draw on their own experiences to explore identity and inequality, solidarity and diversity. ${ }^{139}$ As Supriya Routh eloquently explains,

[c]ommunity clinics place the students, who are generally from reasonably privileged, middle class backgrounds, in uncomfortable situations. The hardships of life that these students have never known become realities as they personally live through them. The importance of the humble requirements of life that they could otherwise never have imagined becomes strikingly distinct and evident to them. ${ }^{140}$

Of course, some clinical scholars - and students - have resisted classroom components as irrelevant, disconnected, or "make-work." 141 These arguments have, by and large, been successfully countered by others who argue that the "opportunity to engage in a deliberate self-reflective analysis about the complexities of carrying out of our work" in the classroom requires and justifies externship experiences. ${ }^{142}$ From this perspective, it is exposure that is easily obtained and time for reflection that is not. Classroom reflection opportunities may also reduce the risk that students will simply reinforce dominant narratives or "fetishize, appropriate, or otherwise problematically approach the reality of suffering" and struggles for justice. ${ }^{143}$

135 Jaszi, supra note 27 at 412.

136 Ibid at 404.

137 Eisinger, supra note 13 at 665.

138 Bellow, supra note 6 at 386.

139 Audrey Osler \& Juanjuan Zhu, "Narrative in Teaching and Research for Justice and Human Rights" (2011) 6:3 Education, Citizenship \& Social Justice 223 at 227.

140 Routh, supra note 21 at 1397. See similarly Mari J Matsuda, "Admit that the Waters around You Have Grown: Change \& Legal Education" (2014) 89 Ind LJ 1381 at 1397; Kevin R Johnson \& Amagda Pérez, "Clinical Legal Education and the UC Davis Immigration Law Clinic: Putting Theory into Practice and Practice into Theory" (1997) 51 SMU L Rev 1423 at 1426.

141 Coss, supra note 133 at 48; Eisinger, supra note 13 at 674. I heard this sort of grumbling in all three of the programs in which I participated.

142 Bettinger-Lopez, supra note 66 at $362.88 \%$ of American externship programs have a mandatory classroom component. David A Santacroce \& Robert R Kuehn, The 2010-11 Survey of Applied Legal Education (Ann Arbor, MI: Center for the Study of Applied Legal Education, 2011), online: <http://www.csale.org/files/CSALE.Report.on.2010-

11.Survey.5.16.12.Revised.pdf $>$ at 24.

143 Sarah Buhler, "Painful Injustices: Encountering Social Suffering in Clinical Legal Education" (2012) 19 Clinical L Rev 405 at 408. See also generally Makau Mutua, "Savages, Victims, and Saviors: The Metaphor of Human Rights" (2001) 


\section{(b) Identity Formation}

No doubt, students seek externship experiences as a way to build or reinforce their professional identity. Many students want to be not just good lawyers but also good people. The distress that is created by legal training and that shakes student identity is well documented. ${ }^{144}$ For some students, externships are sometimes presented as an antidote to the scepticism students learn in the classroom, ${ }^{145} \mathrm{a}$ reminder of altruistic motivations for choosing to attend law school, ${ }^{146}$ or an opportunity to begin forging professional identity. ${ }^{147}$ In short, the theory is that "in the social whirl of practice, students form both temporary alliances and lifelong relationships that support their immediate work performance and their long-term career development ... relationships and interactions including role modelling and emulation, collaboration and mentoring." ${ }^{148}$ These relationships and experiences, it is hoped, will have a long-term influence on the thinking and attitudes of the students who engage in human rights internships. ${ }^{149}$ Indeed, it is on this basis that Kelly Terry argues for externships to be recognized as a signature pedagogy for "the apprenticeship of professional identity."

Of the three programs I experienced, the AHRC was the only program that consciously cultivated a strong group identity both during the program and through its network of alumni. Over the course of the summer, I too was inculcated with the mantra: "Once an intern, always an intern!" Yet even in the AHRC's case, it is not obvious that internships have a long-term influence. More research is clearly needed, but some work already makes the common-sense suggestion that "larger structural incentives, institutional interests, and socio-political realities are likely to have greater influence on the behaviour of lawyers and judges than the legal education they have received." 151 If this is the case, sporadic, but inspiring, student outcomes are insufficient to justify the risks and resources of clinical programming. The key to the signature pedagogy framework is that it helps us move beyond measuring success by student outcomes - outcomes over which educators may have the least control - by asking us to look more deeply at the contributions program structure itself may make to society.

42:1 Harvard Int'l LJ 201; Barbora Bukovská, “Perpetrating Good: Unintended Consequences of International Human Rights Advocacy" (2008) 5:9 Sur: International Journal on Human Rights 7.

Tamara Walsh, "Putting Justice Back into Legal Education" (2007) 17 Legal Educ Rev 119 at 126; Sullivan, supra note 107 at 23. See also, among others, Edward Rubin, "Curricular Stress" (2010) 60 J Legal Educ 110 at 111-112; Rachael Field \& James Duffy, "Better to Light a Single Candle Than to Curse the Darkness: Promoting Law Student Well-Being through a First Year Law Subject" (2012) 12 Queensland U Tech L \& Just J 133 at 155; Lawrence S Krieger, "Institutional Denial about the Dark Side of Law School, and Fresh Empirical Guidance for Constructively Breaking the Silence" (2002) 52 J Legal Educ 112 at 125. Coss, supra note 133 at 33.

146 Kotkin, supra note 8 at 130 . See also Vasey, supra note 14 at 2.

147 Givelber et al, supra note 15 at 12.

$148 \mathrm{Ibid}$ at 12. See also Colin James, "Seeing Things as We Are: Emotional Intelligence and Clinical Legal Education" (2005) 8 International Journal of Clinical Legal Education 123 at 140.

149 Yeh, supra note 10 at 121; Barry, supra note 27 at 35; Shin Imai, "Counter-Pedagogy for Social Justice: Core Skills for Community-based Lawyering” (2002) 9 Clinical L Rev 195 at 207; Marcy L Karin \& Robin R Runge, "Toward Integrated Law Clinics that Train Social Change Advocates" (2011) 17 Clinical L Rev 563 at 567; Sullivan, supra note 107 at 23.

150 Terry, supra note 24 at 243.

151 Yeh, supra note 10 at $127-128$. 


\section{Tacit Structure: Modelling Values and "Being the Change"}

If we could change ourselves, the tendencies in the world would also change. As a man changes his own nature, so does the attitude of the world change towards him. ... We need not wait to see what others do. ${ }^{152}$

- Mahatma Gandhi

If the surface structure organizes the nuts and bolts of a program and the deep structure analyzes motivating objectives, the tacit structure reveals the value ordering implicit in the program structure itself. This level of analysis takes us beyond student outcomes to examine the epistemological and social hierarchies externship structures create, reinforce or challenge. Law schools and universities are "notoriously resistant to being held accountable to empowered community organizations and to answering for the choices that are made in program development." "153 This level of analysis challenges externship programs to step away from this reluctance to evaluate themselves based not on what they aim to teach or the change they seek to effect but on the values they embody through the relationships they cultivate.

\section{(a) Epistemological Hierarchies}

Externships do not occur in random spaces. Few are near coordinating law faculties - economically, culturally, or geographically. ${ }^{154}$ Though students are not encouraged to become poverty "voyeurs" 155 or "tourists," 156 most are transients in their host environments, and a palpable social cachet attaches to exotic placements in any program. ${ }^{157}$ Externship programs must be wary of replicating the dominant exclusionary structures so frequently criticized in international human rights work. ${ }^{158}$ In my experience, externship programs under-prepare students to be aware of their status as visitors, ${ }^{159}$ when even in domestic placements students so often come from "elite backgrounds and form a privileged class or social group." 160

152 Brian Morton, "Falser Words Were Never Spoken" (29 August 2011), New York Times, online: <http://www.nytimes.com/2011/08/30/opinion/falser-words-were-never-spoken.html?_r=1\&>.

153 Ashar, "Law Clinics," supra note 18 at 387. Clearly the dynamics observed here extend well-beyond clinical education and externship programs. The point is not that our programs are solely responsible for their existence or their resolution. Rather, I suggest that we should have a heightened awareness of these dynamics and, at the very least, strive not to contribute to their perpetuation.

154 It is no coincidence that McGill and Ateneo are both located on some of the highest-value property in their respective cities.

155 Bukovská, supra note 143 at 10, citing David Kennedy.

156 Bettinger-Lopez, supra note 66 at 353.

157 Each year, the LCC struggles with student distribution across more or less popular clinics. Over the years, the IHRI has seen student interest shift from overwhelming interest in Africa to interest in Aboriginal issues in Canada. For a fascinating narrative of what self-awareness of these issues feels like in the field, see David Kennedy, "Spring Break" (1984) 63 Tex L Rev 1377.

158 Bukovská, supra note 143 at 15. See also Mutua, supra note 142 at 204.

159 My experiences resonate with those of Johnson \& Pérez, supra note 140 at 1459.

160 Bukovská, supra note 143 at 15. 
Given the importance externship programs place on bringing field experiences back to the classroom, they must operate with heightened awareness of how spatial ordering can symbolize the lesser importance accorded to certain knowledge and persons. ${ }^{161}$ Although the literature articulates the importance of students locating legal knowledge beyond themselves and their faculties, we contradict this message and reinforce a distrust of practitioners as educators ${ }^{162}$ when host supervisors and service users are not invited to reflect in the classroom with us. Worse, we objectify host supervisors and service users by making them subjects of "objective" or "academic" study, ${ }^{163}$ arrogantly presupposing "that academics are able to develop insightful, progressive, useful critique without immersing themselves in the lives of the oppressed." ${ }^{\prime 64}$ Indeed, clinical professors themselves have criticized classroom reflection as a pro-forma means of reinforcing program legitimacy in the eyes of their fellow academics or professional regulatory bodies. ${ }^{165}$

Happily, programs can be restructured to better integrate community and academic knowledge. Host supervisors and service users can be invited as expert panelists for conferences. ${ }^{166}$ They should be invited to contribute to classroom components and academic research. Their participation should be a crucial component in program evaluation. Although the literature on externships and clinical education frequently references the importance of clinical scholarship, it does so virtually exclusively with respect to the status of clinical professors, not externship hosts. ${ }^{167}$ Fostering better research relationships between law professors and externship environments could create a more symbiotic exchange of expertise, with theory benefiting from practice and vice versa. ${ }^{168}$

\section{(b) Money Matters}

Of course, the valuation of expertise goes beyond the symbolic. It emerges concretely through the financial structure of externship programs. The dynamics of who is working, who is paid, and who is paying reveal important inequalities between stakeholders. Students generally pay tuition fees to participate in externship programs - but whom are they paying and in exchange for what? In many instances, faculty involvement is "spotty and irregular," conceived of more as monitoring and troubleshooting than teaching or supervision. ${ }^{169}$ Often, university institutions and professors are being

161 Philip C Kissam, The Discipline of Law Schools: The Making of Modern Lawyers (Durham, NC: Carolina Academic Press, 2003) at 78.

162 Givelber et al, supra note 15 at 8.

163 See, e.g., Jaszi, supra note 27.

164 Mosher, "Legal Education," supra note 34 at 632.

165 Eisinger, supra note 13 at 673. See also Alviar, supra note 6 at 208: "[T]here has always been a group of jurists who consider the antiformalist, interdisciplinary, sociological approach as useless, unscientific, 'not really law', and potentially dangerous."

166 Blanco \& Buhai, supra note 133 at 911 . Host supervisors were, for example, invited to sit as expert panelists at the Legal Information Clinic at McGill's 40th anniversary conference held 18 October 2013 as well as at a town hall meeting on unpaid student work also held at McGill on 30 October 2013.

167 See, among others, McCrate Report, supra note 75 at 245; Stuckey, Best Practices, supra note 27 at 131; Voyvodic, supra note 66 at 114; Frank S Bloch, "The Case for Clinical Scholarship" (2004) 4 International Journal of Clinical Legal Education 7.

168 For contrast, see scholarship related to my LCC host produced by students and professors in other fields. See $<$ https://danslarue.org/a-propos/partenariats-engagements/>.

169 Coss, supra note 133 at 44. 
paid tuition dollars for work - teaching and supervision - that is in fact being done by supervisors and service users in the host environment. ${ }^{170}$ This was certainly the case with McGill's LCC and largely true of the experiential portion of the IHRI. Surely, it is possible for students to learn from loosely structured or unsupervised externship placements without explicit clinical methodology or objectives - in fact, this is "precisely what occurs in most employment situations for most people." 171 There is, however, a difference between experiential learning - the learning that occurs in any situation - and experiential education that is an intentionally designed and guided learning process. ${ }^{172}$ Where an externship "does not offer more educational value to the student than a job or volunteer experience, then the law school should not be charging for it and students should not be paying for or getting credit for random experience." 173

Host environments will undoubtedly receive some benefit from student work, even if that benefit is not a cash transfer of tuition dollars. Indeed, many hosts welcome students who bring extra hands and institutional prestige and because they cannot afford to pay an equivalent number of salaried workers. ${ }^{174}$ Some hosts operate in financial realities that would not allow them to continue opening their doors to service users without unpaid student workers. ${ }^{175}$ But we must take care not to overestimate the utility of student externs ${ }^{176}$ or to forget that the resources required for their supervision are frequently offered as a rationale for choosing the externship platform. ${ }^{177}$ If law faculties cannot afford supervised, in-house clinics, we must think critically about how that resource burden is shifted by the creation of externship programs. While financial implications will most certainly differ across universities and host environments, ${ }^{178}$ it is inappropriate for externship programs to be "downloading their responsibilities to

170 Ibid at 40; Walsh, supra note 144 at 139; Mosher, "Carnegie, Professionalism," supra note 81 at 9; and David L Gregory, "The Problematic Employment Dynamics of Student Internships" (1998) 12 Notre Dame JL Ethics \& Pub Pol'y 227 at 260. The stakes will, of course, be different for public and private universities not only because of the amounts of funding that are available but also because of the source of that funding. Although some of my colleagues argue that public education funding in Quebec should not be funneled to movement-oriented organizations on the basis of political neutrality, this argument is unpersuasive insofar as it ignores the political implications of any legal education. At any rate, the point here is less the amount of available funding than the importance of taking a principled approach to its distribution.

171 Eyster, supra note 108 at 385, 388.

172 Vasey, supra note 14 at 15.

173 Maurer \& Cole, supra note 10 at 142; Ogilvy, supra note 24 at 163.

174 Gregory, supra note 170 at 242; Berman, supra note 33 at 440.

175 Susan Harthill, "Shining the Spotlight on Unpaid Law Student Workers" (2014) 38 Vt L Rev 556 at 556. This was a very real concern for two LCC hosts in 2014.

176 Many scholars warn against overconfidence in student capacities, see, e.g., Maurer \& Cole, supra note 10 at 151 ; Imai, supra note 149 at 199 . Unfortunately, many also seem to think "their" students are the exception to the rule. See, e.g., Hurwitz, supra note 20 at 546, noting that certain work may not be appropriate for the "average" student "but it has been effective for [Rutgers's] bright, motivated crew. We do not waste a lot of time teaching what is, to most of these students, obvious and self-evident." See also Lucie E White, "The Transformative Potential of Clinical Legal Education" (1997) 35 Osgoode Hall LJ 603 at 609, for a summary of theories that debunk the claim that the academic "vanguard" can "change the world."

178 See, among others, Coss, supra note 133 at 29; Jaszi, supra note 27 at 411; Walsh, supra note 144 at 139.

Observing who declines to participate because of resource requirements may also be instructive. See, e.g., Philip F Iya, "Enhancing the Teaching of Human Rights in African Universities: What Role for Law School Clinics?" (2005) 7 Int'1 J Clinical Legal Education 20 at 27. 
teach students onto resource-strapped organizations without providing commensurate support and resources." 179 Where the contributions of host supervisors and service users are not meaningfully acknowledged, externship programs contribute to a devaluation of their work and communicate to students that such work should be seen as volunteer side-work rather than taken seriously as a professional pursuit. ${ }^{180}$

The message that human rights work is a luxury - or, at least, not work that merits remuneration - is compounded by policies prohibiting students from receiving university credit for paid work. ${ }^{181}$ Such policies may give rise to "a troubling class divide between [students] who can afford the luxury of unpaid experience and those who cannot." ${ }^{\text {"182 }}$ Students who cannot afford to pay tuition and living costs without working will face limitations in their opportunities to gain experience, which may impede them from seeking such work in the future ${ }^{183}$ Even a student who works for free is in a better position than if he or she did not pay thousands of dollars for academic credit to a faculty who simply "puts credits on transcripts." ${ }^{184}$ Although students with high future earning potential may not be the most sympathetic of actors, ${ }^{185}$ law schools should be encouraging students to find ways to balance their social justice commitments with financial realities. ${ }^{186}$ Programs that subsidize externship costs, as do the IHRI and the AHRC, can begin to address some of these barriers. ${ }^{187}$

179 Mosher, "Carnegie, Professionalism," supra note 81 at 9.

180 Adam Vasey makes interesting comments in this regard. See Vasey, supra note 14 at 11.

181 Givelber et al, supra note 15 at 45; James H Backman, "Where Do Externships Fit? A New Paradigm Is Needed: Marshaling Law School Resources to Provide an Externship For Every Student" (2006) 56:4 J Legal Educ 615 at 617. During my time as coordinator of the LCC, we wrestled with this issue and ultimately decided that students could be awarded credit for paid internships completed in non-profit organizations.

182 Debra D Burke \& Robert Carton, "The Pedagogical, Legal and Ethical Implications of Unpaid Internships" (2013) 30:1 Journal of Legal Studies Education 99 at 123.

183 I was shocked when a recent IHRI alumna began her debrief comments by stating "This is my sixth human rights internship." I was shocked not because of her experience, but because the tone of her remarks seemed to indicate that this was just another experience to toss on the pile. I found this regrettable, given the number of students who had not participated in any internship precisely because they could not afford to spend a summer without working for money. Anecdotally, I also wonder if externship patterns - predominantly sought and taught by women (see Santacroce \& Kuehn, supra note 142 at 26; Walsh, supra note 144 at 133) - contribute to gendered patterns of employment in human rights. In Montreal alone, several of our hosts are female lawyers whose ability to work for low or no pay is subsidized by their husbands' income in the corporate sector.

184 Gregory, supra note 170 at 260.

185 Ibid at 263, reporting that Yale had announced to TAs "there is no need to pay graduate students a 'living wage' because a Yale degree assures them of a high paying job. However, Yale is not exempt from the rest of the economy; the graduate assistants are not the 'blessed of the earth'."

186 Nekima Levy-pounds \& Artika Tyner, "The Principles of Ubuntu: Using the Legal Clinical Model to Train Agents of Social Change" (2008) 13 Int'l J Clinical Legal Education 7 at 10.

187 The IHRI provides significant funding to mitigate student costs. The AHRC also sponsors students from other universities as "replicate" students, hoping to inspire and empower these "replicate" students to return and found similar programs at their home universities. See Internship Program, supra note 4 at 4. 


\section{(c) Systemic Impacts}

Clinical legal education may be the Trojan horse that fails to disturb and sometimes even promotes subordination through law.

- Sameer Ashar ${ }^{188}$

Finally, relationships between externship stakeholders communicate important messages about who should be protected. Although externships and student clinics have been justified as a means of redistributive justice and providing access to justice to the poor, it is unclear that students are the proper place to locate responsibility for answering access to justice problems. ${ }^{189}$ Service users may be "harmed by the efforts of students, many of whom after all cannot be expected to render fully competent legal services because of their inexperience." ${ }^{\prime 190}$ Students are not lawyers. It is not about being right all of the time - even good lawyers, like students, will make mistakes, and reasonable people may differ with respect to the proper approach to a given problem. ${ }^{191}$ But where externship programs fail to give importance to the legal assistance extended to the poor - by marginalizing externship programs in the curriculum, by failing to provide adequate resources, and by marginalizing hosts and service users such programs contribute to rather than address the access to justice problem, perpetuating a system of access based on the notion that legal aid is not a right but something "those who have the good fortune to be entering a lucrative career should donate ... to those less fortunate in society." 192 Especially at a time when the Supreme Court of Canada is taking steps towards recognizing the fundamental rights engaged by questions of access to justice, ${ }^{193}$ externship programs should be sharply aware of the implications their structures have in sustaining systems that discriminate against users on the basis of socio-economic status. ${ }^{194}$ Obviously, this does not mean that students should not work with host organizations. But, the implicit messages program structure sends about the role of human rights work and who it protects should call into question the role that externship programs play in furthering marginalization and subordination. If one of our goals is to teach social justice "... it remains essential that we understand how these institutions succeed in redistributing power in a particular context to replicate success, to avoid pitfalls and to contribute to the development of new theoretical frameworks, including future iterations of law and development theory."195

\footnotetext{
188 Ashar, "Book Review," supra note 19 at 202.

189 Alviar, supra note 6 at 209; Barry, Dubin \& Joy, supra note 27 at 36; Bloch \& Prasad, supra note 6 at 172.

190 Stuckey, "Ensuring Basic Quality," supra note 99 at 49.

191 Blanco \& Buhai, supra note 133 at 927.

192 Gledhill, supra note 30 at 302; Vasey, supra note 14 at 4.

193 Compare Trial Lawyers Association of British Columbia v British Columbia (AG), 2014 SCC 59 with British Columbia (AG) v Christie, 2007 SCC 21, [2007] 1 SCR 873.

194 Gledhill, supra note 30 at 303, arguing that the right to non-discriminatory access to representation is embraced by Articles 2 and 26 of the International Covenant on Civil and Political Rights, 16 December 1966, 999 UNTS 171.

195 Ashar, "Book Review," supra note 19 at 199.
} 


\section{CONCLUSION}

Externship programs have had many incarnations, and there are undoubtedly many left to come. Given the clear intention to continue investing in these programs and the resource shortages all stakeholders face, we must begin evaluating these programs. The goals we set will determine how we evaluate our progress. In the past, externship evaluation has focused on short-term student-learning outcomes and long-term student decision making. I have argued that these goals are unhelpfully narrow, given they account for the experiences of only some stakeholders and are based on slippery causal assumptions. Externship programs that seek to teach social justice should broaden the evaluative lens and embrace the perspectives and participation of all stakeholders. One way of doing this is to use the signature pedagogy model that asks us to evaluate not only our surface actions and objectives but also the implicit values that the structures of our programs embody and communicate. ${ }^{196}$ I hope these reflections will stimulate stakeholders to find their own meaningful ways of reviewing and evaluating whether their externship programs are engaging in the kind of change they seek to promote.

196 Shulman, supra note 104. 